\title{
PENGEMBANGAN ANIME (ANIMATION LEARNING MEDIA) BERBASIS MULTIMEDIA UNTUK PEMBELAJARAN DASAR SISTEM KOMPUTER BAHASAN INSTALASI HARDWARE
}

\author{
I Made Gede Sunarya ${ }^{1}$, I Gede Mahendra Darmawiguna² \\ ${ }^{1,2}$ Pendidikan Teknik Informatika, Fakultas Teknik dan Kejuruan \\ Universitas Pendidikan Ganesha \\ Singaraja, Indonesia
}

e-mail : imadegedesunarya@gmail.com, igd.mahendra.d@gmail.com

\begin{abstract}
Abstrak
Penelitian ini bertujuan untuk merancang, mengimplementasi Anime (Animation Learning Media) Berbasis Multimedia untuk Pembelajaran Dasar Sistem Komputer Bahasan Instalasi Hardware serta mengetahui respon mahasiswa terhadap penerapan Anime berbasis multimedia tersebut. Metode yang digunakan dalam penelitian ini adalah metode penelitian pengembangan (Research and Development). Desain pengembangan yang digunakan adalah model Dick \& Carey. Pengembangan Anime sebagai sebuah produk akhir dari penelitian ini menggunakan metode pengembangan yang disebut System Development Life Cycle (SDLC) berbasis Waterfall yang merupakan standar pengembangan sebuah perangkat lunak. Validasi yang dilakukan dalam pengujian produk yaitu validasi produk secara teknis, validasi oleh para ahli dan uji terbatas. Pengumpulan data dilakukan dengan cara pemberian angket kepada mahasiswa. Data yang terkumpul dianalisis secara statistik deskriptif. Rancangan dan implementasi media anime terdiri dari 3 menu utama, yaitu menu pengenalan hardware, menu perakitan komputer, menu troubleshooting komputer. menu pengenalan hardware terdiri dari 4 sub menu, yaitu alat input, alat output, alat pemroses, alat penyimpanan. Menu perakitan komputer terdiri dari submenu perakitan tanpa casing dan perakitan dengan casing. Respon mahasiswa terhadap pengembangan media anime dalam kategori sangat positif.
\end{abstract}

Kata kunci: Anime, Media Pembelajaran, Dasar Sistem Komputer

\begin{abstract}
This study aims to design, implement Anime (Animation Learning Media) Multimedia-Based System for Learning Basic Computer Hardware Discussion Installation and evaluate the response of students to the application of the multimedia-based anime. The method used in this research is the development of research methods (Research and Development). Design development models used are Dick \& Carey (Santyasa, 2009). Development of Anime as an end product of this research is the development method called the System Development Life Cycle (SDLC) Waterfall which is based on a standard software development. Validation tests are conducted in a product that is technically product validation, validation by experts and a limited test. The data was collected by way of
\end{abstract}


questionnaires to students. Data were analyzed by descriptive statistics. Anime design and implement consists of 3 main menu, that menu is the introduction of the hardware, computer assembly menus, computer troubleshooting menus. Hardware identification menu consists of 4 sub-menu, that is input devices, output devices, processors devices, storage devices. Computer assembly menus consists of submenus computer assembly without casing and computer assembly in casing. Response of students towards anime is very positive.

Keywords: Anime, Learning Media, Basic Computer Systems

\section{PENDAHULUAN}

Pendidikan merupakan istilah yang umum dipahami sebagai proses untuk menjadikan seseorang menjadi lebih pintar atau cerdas. Pada kenyataannya, pendidikan memiliki aspek yang lebih luas dan konsep yang lebih mendalam lagi. Proses pendidikan terarah pada peningkatan pengetahuaan, penguasaan keterampilan, pengembangan sikap dan nilai-nilai dalam rangka pembentukan dan pengembangan diri peserta didik, Pendapat ini menitikberatkan nilai pendidikan pada upaya untuk meingkatkan kualitas manusia secara fisik maupun psikologis, dan tidak hanya aspek kognisi seperti yang umum dipahami. Pengembangan teknologi pendidikan telah banyak dilakukan dan dimanfaatkan. Teknologi pendidikan ini diharapkan akan dapat membantu proses pendidikan secara umum maupun khusus sehingga apa yang ingin dicapai melalui proses pendidikan dapat diperoleh dengan baik. Walaupun masih dapat diperdebatkan, peran prinsip dari teknologi pendidikan ini adalah untuk membantu peningkatan efisiensi proses belajar mengajar secara keseluruhan (Darmawan, 2006).

Universitas Pendidikan Genesha memiliki visi Sebuah Lembaga Pendidikan Tinggi berkualitas yang dikembangkan berdasarkan Pancasila dan Undang Undang dasar 1945, yang menjunjung nilai-nilai kemanusiaan, menghasilkan Tenaga Kependidikan dan Tenaga Non-Kependidikan yang bertaqwa kepada tuhan Yang Maha Esa, memiliki kemampuan akademisprofesional yang tinggi, mengembangkan ilmu pengetahuan, teknologi, dan seni sehingga mampu menghadapi masa depan serta memenuhi kebutuhan masyarakat. Jurusan Pendidikan Teknik Informatika (PTI) merupakan salah satu manifestasi visi Undiksha dalam pengembangan bidang teknologi khususnya teknologi dalam bidang komputer dan Teknologi informasi dan komunikasi (http://www.undiksha.ac.id).

Pembelajaran pada jurusan PTI menyentuh ranah teknologi hardware komputer. Hardware komputer merupakan perangkat keras komputer yang merupakan bagian dari sistem komputer. Sistem komputer terdiri dari 3 bagian yaitu hardware, software dan brainware. Tanpa ketiga bagian tersebut, maka sistem komputer tidak akan berjalan dengan baik. Hardware komputer berbentuk item fisik yang dapat dilihat dan diraba. Pengenalan hardware dan proses instalasinya memerlukan jumlah peralatan yang banyak untuk masing-masing mahasiswa. Hardware komputer merupakan alat elektronik yang bersifat 
rentan rusak dan harga masing-masing hardware relatif mahal. Kerena keterbatasan hardware yang ada maka pengenalan hardware berupa visualisai berbentuk animasi multimedia bisa dilakukan.

Animasi merupakan pembentukan gerakan dari berbagai media atau objek yang divariasikan dengan gerakan transisi, efek-efek, juga suara yang selaras dengan gerakan animasi tersebut atau animasi merupakan penayangan frame-frame gambar secara cepat untuk menghasilkan kesan gerakan (Sutopo dalam Juaheri, 2010). Menurut Chanlin dalam Hobban dan Ferry (tt), Animation is the optical illusion created by moving images of objects at high speed, usually 24 frames per second, so that the viewer gets an impression that the object is moving or alive. Animasi merupakan ilusi optik gambar yang diciptakan oleh obyek bergerak dengan kecepatan tinggi, biasanya 24 fps (frame per second), sehingga pengamat mendapat kesan bahwa objek bergerak atau hidup.

Yigal Rosen (2009) menemukan dampak yang signifikan dari lingkungan belajar berbasis animasi on-line dalam hal transfer pengetahuan dan motivasi belajar. Selain itu, temuan menunjukkan bahwa mahasiswa mengubah persepsi mereka tentang ilmu pengetahuan dan teknologi pembelajaran sebagai hasil pengajaran dan pembelajaran dengan animasi terintegrasi. Mahasiswa merasa bahwa diri mereka memainkan peran yang lebih penting dalam interaksi kelas, merasa lebih menarik dalam belajar, dan lebih menekankan penggunaan teknologi dan percobaan selama pelajaran (Rosen, 2009). Robbins (1998) dalam penelitiannya menyatakan keberhasilan penggunaan animasi komputer dalam mengajarkan konsep microprogramming untuk jurusan ilmu komputer (Robbins, Steven, Kay A. Robbins, 1998). Hasrul (2011) melakukan penelitian tentang pemanfaatan media animasi berbasis adobe flash cs3 pada mata kuliah instalasi listrik 2. Hasil yang diperoleh dalam pemelajaran adalah berada di atas rata-rata dengan kategori baik. Sunarya dan Wirawan (2010) melakukan penelitian tentang pemanfaatan animasi untuk Pembelajaran Komunikasi Data Bahasan Protokol dan Arsitektur Protokol. Beberapa penelitian pengembangan media berbasis animai atau multimedia telah dilakukan oleh Kristanto (2011), Rahmattullah (2011), Lisana (2011), Rahman dan Ishafit (2011).

Berdasarkan hasil pengamatan
pada saat berlangsungnya
pembelajaran mata kuliah Dasar Sistem
Komputer bahasan pengenalan hardware dan instalasi hardware terlihat bahwa kekhawatiran terlihat pada mahasiswa yang melakukan proses instalasi hardware. Harga yang relatif mahal dan kerentanan kerusakan hardware menjadi salah satu faktor penyebabnya. Keterbatasan alat juga menyebabkan mahasiswa secara perseorangan tidak dapat mengeksplorasi masing-masing hardware dan tidak bisa melakukan proses instalasi hardware secara individu.

Berdasarkan permasalahan yang dihadapi pada proses pembelajaran pada semester tersebut dan adanya hasil pemikiran beberapa peneliti dalam bidang animasi dan multimedia, maka 
telah dilakukan sebuah penelitian yang berjudul "Pengembangan ANIME (Animation Learning Media) Berbasis Multimedia untuk Pembelajaran Dasar Sistem Komputer Bahasan Instalasi Hardware (Studi Kasus pada Jurusan Pendidikan Teknik Informatika Undiksha).

Teknologi komputer adalah sebuah penemuan yang memungkinkan menghadirkan beberapa atau semua bentuk stimulus sehingga pencapaian hasil pembelajaran secara optimal. Pengajar akam melakukan bentukbentuk stimulus yang dipergunakan sebaga media, di antaranya adalah hubungan atau interaksi antar manusia, yaitu: realitas, gambar bergerak dan bambar diam, tulisan dan suara yang direkam. Kelima bentuk stimulus ini akan membantu pembelajaran dalam proses pembelajaran. Pengajar adalah orang yang mempunyai kemampuan untuk merealisasikan kelima bentuk stimulus tersebut dalam bentuk pembelajaran. Tetapi kesulitan yang dihadapi adalah kembanyakan pengajar tidak mempunyai kemampuan untuk menghadirkan kelima stimulus itu dengan program komputer.

Media berasal dari bahasa latin merupakan bentuk jamak dari "Medium" yang secara harfiah berarti "Perantara" atau "Pengantar" yaitu perantara atau pengantar sumber pesan dengan penerima pesan. Pengertian umumnya adalah segala sesuatu yang dapat menyalurkan informasi dari sumber informasi kepada penerima informasi. Media menurut AECT adalah segala sesuatu yang digunakan orang untuk menyalurkan pesan. Sedangkan Gagne mengartikan media sebagai jenis komponen dalam lingkungan siswa yang dapat merangsang mereka untuk belajar. Briggs mengartikan media sebagai alat untuk memberikan perangsang bagi siswa agar terjadi proses belajar (Sudrajat, 2009).

Hardware atau perangkat keras adalah bagian komputer yang bisa kita lihat wujud fisiknya. Hardware komputer tersusun dari komponen komponen elektronika dan mekanis yang dirakit membentuk modul-modul yang diberi nama sesuai dengan fungsinya. Beberapa jenis hardware komputer adalah :

a. Motherboard

Motherboard atau dalam bahasa Indonesia adalah Papan Induk merupakan media dasar dari berbagai komponen CPU komputer. Motherboard merupakan papan sirkuit yang dipasang berbagai kom ponen, di antaranya Processor, RAM, VGA, Audio Card, LAN Card, dan berbagai komponen lainnya.

b. Processor

Processor atau nama lengkapnya Microprocessor ( $\mu \mathrm{P})$ adalah sebuah komponen yang terbuat dari transistor mini beserta sirkuit lain di atas sebuah sirkuit terintegrasi semikonduktor yang bekerja sebagai inti atau otak dari komputer. CPU (Central Processing Unit) merupakan istilah asli dari Processor yang kemudian oleh sebagian orang diang - gap sebagai kesuluruhan mesin komputer. Media yang digunakan untuk mendinginkan dan menyerap panas yang dihasilkan oleh processor

c. Harddisk

Media penyimpanan data permanen, jadi data tidak hilang meskipun listrik sudah dimatikan. Harddisk berisi 
sebuah cakram magnetik yang mampu menyimpan data.

d. RAM (Random Access Memory)

Memory atau dalam istilah lain RAM (Random Access Memory) adalah jenis media penyimpanan komputer yang dapat diakses secara acak. Artinya, urutan memory yang disimpan dapat dilakukan secara acak dan tidak berurutan, seperti halnya disk. RAM juga difungsikan sebagai memori utama (main memory) untuk menampilkan dan memanipulasi data pada saat komputer pertama dinyalakan, dan akan terhapus bila komputer mati.

e. Optical Drive

alat pembaca untuk media penyimpan data berupa disk DVD / CD. DVD/ CD berupa kepingan cakram optik yang berisi data.

f. Floppy Disk

adalah alat pembaca untuk media penyimpan data berupa disk DVD / CD. DVD/ CD berupa kepingan cakram optik yang berisi data. Disket adalah media penyimpan data portabel yang bisa dibawa-bawa. Disket terbuat dari sebuah cakram dari plastik magnetik.

g. VGA Card

singkatan dari Video Graphics Array. VGA Card berfungsi mengeluarkan output grafis (gambar) untuk ditampilkan pada monitor. Ukuran VGA Card ditentukan dari ukuran RAM nya, semakin besar RAM sebuah VGA Card maka semakin halus gambar yang dihasilkan.

h. Sound Card

bagian yang mendekode data data digital menjadi sinyal suara. Dengan penemuan soundcard maka perkembangan dunia multimedia pada komputer menjadi makin meluas. Sound Card yang baik mampu menghasilkan suara dengan sampling yang rapat dan halus sehingga suara yang dihasilkan mendekati suara asli.

i. Keyboard

sebuah papan ketik yang berisi semua model huruf, angka, karakter dan tanda baca yang menjadi sarana bagi pengguna komputer dalam memasukkan data ke komputer. Tombol tombol pada keyboard mengikuti model tombol pada mesin ketik manual.

j. Mouse

sebuah alat pointer untuk mengakses melalui layar monitor

k. Monitor

media tampilan gambar haril output dari VGA Cards. Dahulu monitor komputer dimulai dengan monitor tabung hitam-putih, monitor warna CGA, VGA, dan SVGA. Kini monitor yang sedang populer adalh monitor LCD. LCD mempunyai beberapa kelebihan, antara lain : tipis, hemat biaya dan tingkat radiasi yang rendah.

\section{METODE Uraian Pendekatan}

Metode yang digunakan dalam penelitian ini adalah metode penelitian pengembangan (Research and Development). Desain pengembangan yang digunakan adalah model Dick \& Carey (Santyasa, 2009). Pengembangan Anime sebagai sebuah produk akhir dari penelitian ini menggunakan metode pengembangan yang disebut System Development Life Cycle (SDLC) berbasis Waterfall yang 
merupakan standar pengembangan sebuah perangkat lunak.

Validasi yang dilakukan untuk produk dari penelitian ini dibagi menjadi 3 tahapan, yaitu Validasi produk secara teknik, Validasi produk oleh para ahli, Penerapan terbatas,

Sesuai dengan desain pengembangan Model Dick and Carey, dan dengan penyisipan proses pengembangan perangkat lunak SDLC, tahap-tahap pengembangan dilakukan dalam lima tahap, sebagai berikut :

Tahap Pertama : menentukan mata kuliah yang menjadi obyek pengembangan

Tahap Kedua : analisis kebutuhan

Tahap Ketiga :

proses

mengembangkan draft dan rancangan perangkat lunak

Tahap Keempat : implementasi perangkat lunak

Tahap Kelima : Pengujian (technical test, tinjauan ahli media dan uji coba terbatas)

Analisis kebutuhan yang dilakukan akan memperhatikan 3 dimensi, yaitu (1) nilai-nilai yang diinginkan dan nilainilai yang ada pada saat ini dalam pembelajaran (2) ciri dan karakteristik yang dibutuhkan mahasiswa, dan ciri dan karakteristik yang ada pada saat ini; dan (3) ciri dan karakteristik yang diinginkan pelaksana pendidikan di lapangan pada saat ini. Analisis kebutuhan ini berlangsung secara berkelanjutan mengikuti siklus, karena media akan mengalami penyesuaian sesuai dengan perubahan, tuntutan kebutuhan, dan perkembangan masyarakat. Tahap ketiga merupakan tahap pengembangan draf dari media yang akan dikembangkan.
Tahap keempat merupakan tahap perancangan perangkat lunak yang berupat media pembelajaran berbasis animasi. Pengembangan media ini akan disesuaikan dengan pengembangan perangkat lunak dengan model SDLC. Model SDLC memiliki 5 tahapan umum yaitu :

1. Perencanaan

2. Analisis

3. Perancangan (Design)

4. Implementasi

5. Pengujian dan Perawatan (Maintenance)

Dalam perancangan media berbasis animasi cdalam penelitian ini, penulis mengedopsi dari pengembangan perangkat lunak model SDLC. Gambar 1 menunjukkan bagan tahapan SDLC yang dikembangkan untuk penelitian ini.

Tahap kelima yang merupakan tahap terakhir dari desain pengembangan adalah tahapan pengujian perangkat lunak, tinjauan ahli media dan uji coba terbatas. Pengujian perangkat lunak (technical test) meliputi pengujian fungsionalitas perangkat lunak untuk melakukan :

1. Kesesuaian penamaan hardware

2. Kesesuainan hardware dan fungsinya

3. Kesesuaian posisi peletakan hardware

4. Kesesuaian pemasangan kabel dalam istalasi

5. Kesesuaian jenis slot dengan hardware

6. Kesesuaian ketepatan pemilihan hardware yang akan diinstalasi

Komponen evaluasi oleh ahli isi, media dan desain pembelajaran mencakup kelayakan isi, kebahasaan, sajian, dan kegrafikan. 
Komponen kelayakan isi mencakup, antara lain:

1. Kesesuaian dengan SK, KD

2. Kesesuaian dengan perkembangan anak

3. Kesesuaian dengan kebutuhan bahan ajar isi Kebenaran substansi materi pembelajaran

5. Manfaat untuk penambahan wawasan

6. Kesesuaian dengan nilai moral, dan nilai-nilai sosial

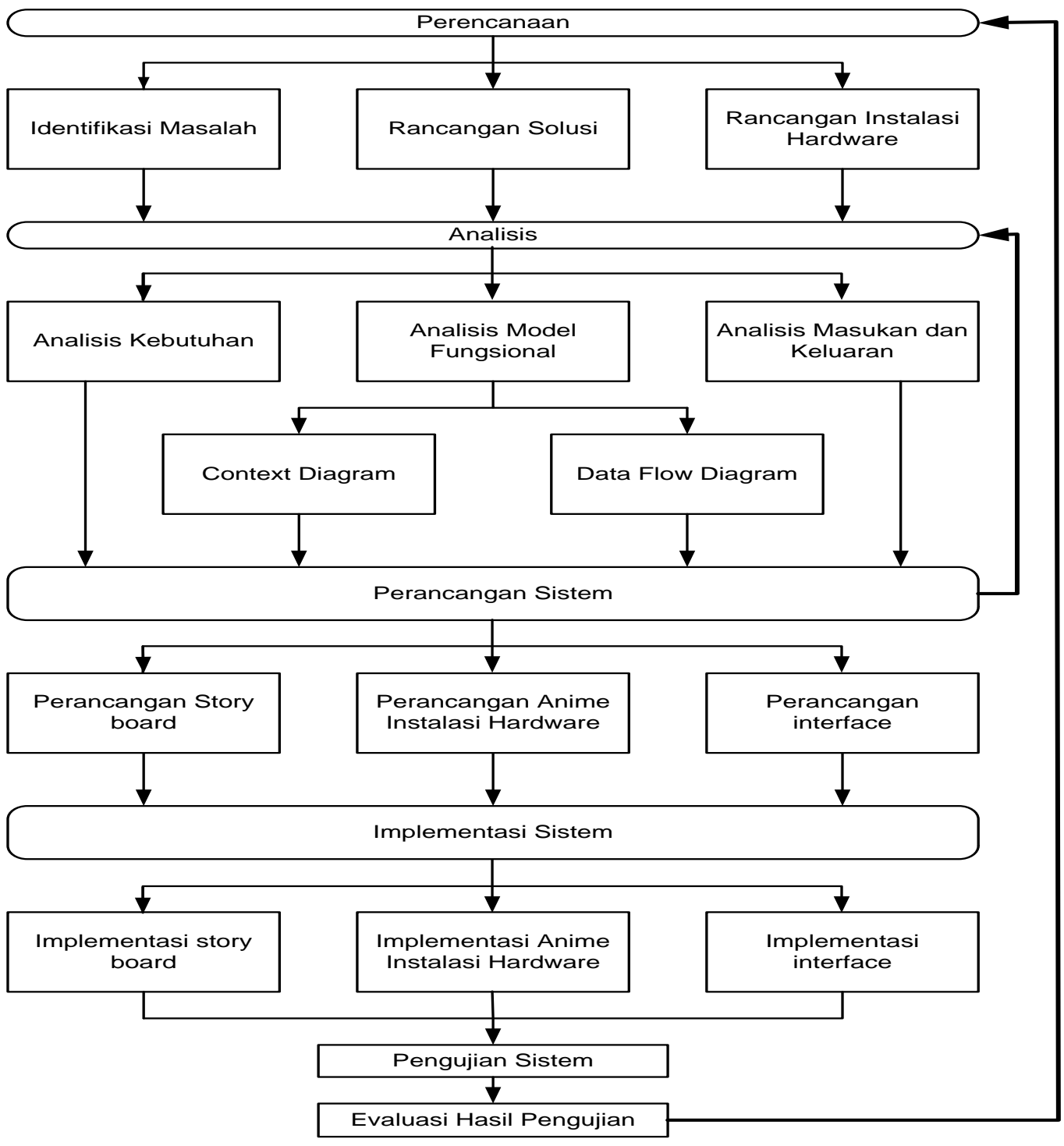

Gambar 1 Tahap Keempat Penelitian 
Komponen Kebahasaan antara lain mencakup:

1. Keterbacaan

2. Kejelasan informasi

3. Kesesuaian dengan kaidah Bahasa Indonesia yang baik dan benar

4. Pemanfaatan bahasa secara efektif dan efisien (jelas dan singkat)

Komponen Penyajian antara lain mencakup:

1. Kejelasan tujuan (indikator) yang ingin dicapai

2. Urutan sajian

3. Pemberian semangat belajar, daya tarik

4. Interaksi (pemberian stimulus dan respons)

5. Kelengkapan informasi

Komponen Kegrafikan antara lain mencakup:

1. Penggunaan font; jenis dan ukuran

2. Lay out atau tata letak

3. Ilustrasi, gambar, foto

4. Desain tampilan

Berdasarkan hasil evaluasi dan pembahasan yang dilakukan oleh para ahli, maka akan dilakukan revisi pada produk yang dikembangkan.

\section{Subjek Penelitian}

Subjek penelitian yang digunakan pada uji terbatas perorangan dan kelompok kecil adalah 12 orang mahasiswa yang sudah pernah mengambil mata kuliah Dasar Sistem Komputer. Subjek penelitian yang digunakan untuk uji coba lapangan dari produk yang dihasilkan adalah mahasiswa semester I Jurusan Pendidikan Teknik Informatika tahun ajaran 2013/2014 yang mengambil mata kuliah Dasar Sistem Komputer

\section{Objek Penelitian}

Objek penelitian dalam penelitian ini adalah ANIME (Animation Learning Media) Berbasis Multimedia untuk Pembelajaran Dasar Sistem Komputer Bahasan Instalasi Hardware.

\section{Pengumpulan dan Analisis Data}

Data dikumpulkan mengunakan instrumen pengujian teknik, pengujian ahli media, pengujian ahli isi, angket respon mahasiswa. Data respon mahasiswa dianalisis dengan menggunakan statistik deskriptif dan penyimpulannya didasarkan atas Mean Ideal (Mi) dan simpangan baku ideal (Si). Respons mahasiswa digali menggunakan kuesioner dengan skala likert 5 (nilai dari 1 sampai 5). Analisis uji ahli media dianalisis dengan metode kualitatif deskriptip, saran dari masingmasing ahli akan dianalisis dalam proses revisi dan bahan evaluasi untuk kesempurnaan dari produk media yang akan dihasilkan.

\section{HASIL DAN PEMBAHASAN \\ Pengembangan Perangkat Lunak}

$$
\text { Matakuliah Dasar Sistem }
$$

Kumputer merupakan mata kuliah di jurusan Pendidikan Teknik Informatika yang membahasa tentang Sistem Komputer yang terdiri dari Hardware, Software dan Brainware. Berdasarkan hasil pengamatan pada saat berlangsungnya pembelajaran mata kuliah Dasar Sistem Komputer bahasan pengenalan hardware dan instalasi hardware terlihat bahwa kekhawatiran terlihat pada mahasiswa yang melakukan proses instalasi hardware. Harga yang relatif mahal dan kerentanan kerusakan hardware menjadi salah satu faktor penyebabnya. 
Keterbatasan alat juga menyebabkan mahasiswa secara perseorangan tidak dapat mengeksplorasi masing-masing hardware dan tidak bisa melakukan proses instalasi hardware secara individu. Teknologi Pembelajaran berbasis komputer berbasis multimedia diterapkan untuk mengatasi permasalahan tersebut.

Kebutuhan fungsional media ini adalah mampu menampilkan materi tentang pengenalan hardware komputer, video perakitan komputer dan troubleshooting komputer.

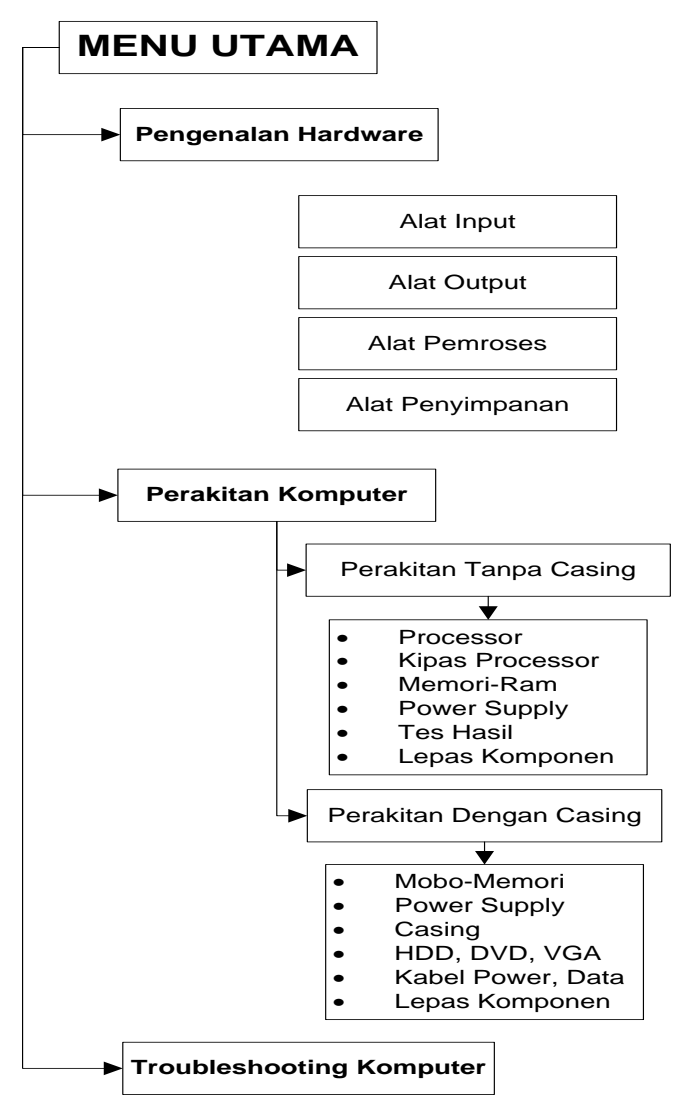

Gambar 3 Arsitektur Perangkat Lunak
Perangkat lunak yang digunakan dalam pengembangan adalah Adobe Flash CS5, Adobe Photoshop, Adobe Premier, Xilisoft Video Converter. Perangkat keras yang digunakan untuk pengemban memilifi spesifikasi Processor Core i5 3230M, Memori 4GB, HDD 500 GB, VGA Intel Graphics 4000. Arsitektur rancangan dari media pembelajaran ANIME ditunjukkan pada Gambar 2. Perancangan GUI (Graphical User Interface) menu utama ditunjukkan pada Gambar 3.

\section{DASAR SISTEM KOMPUTER}

Pengenalan dan Perakitan Komputer

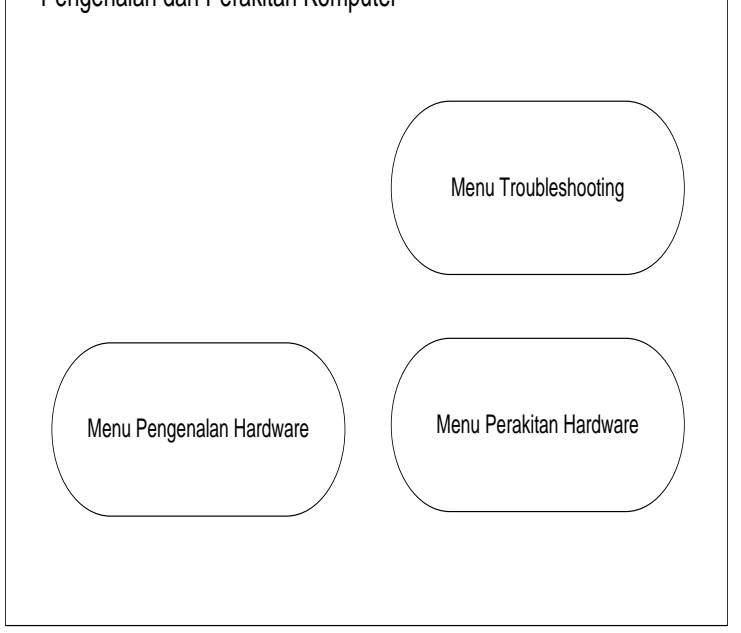

Gambar 2 Menu Utama 
Pada menu utama, terdapat 3 menu yaitu menu Pengenalan Hardware, menu Troubleshooting, menu Perakitan Hardware.

Pada menu Perakitan komputer, terdapat 3 pilihan sub menu, yaitu perakitan Tanpa Casing dan Perakitan dengan Casing. Menu Perakitan Tanpa Casing terdiri dari menu Processor, Kipas Processor, Memori-Ram, Power Supply, Tes Hasil dan Lepas Komponen. Menu

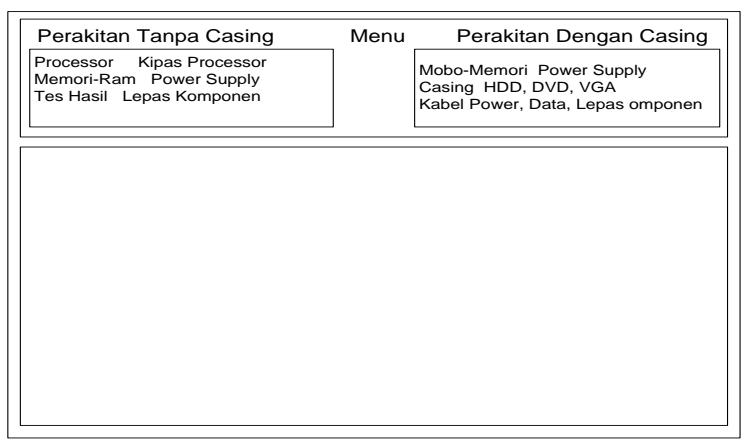

Gambar 4 Rancangan Menu Perakitan Komputer
Perakitan Dengan Casing terdiri dari sub menu Mobo-Memori, Power Supply, Casing, HDD, DVD, VGA, Kabel Power, Kabel Data, Lepas Komponen. Perancangan GUI Menu Troubleshooting ditunjukkan pada Gambar 3.

Perancangan GUI Menu Troubleshooting ditunjukkan pada Gambar 5.

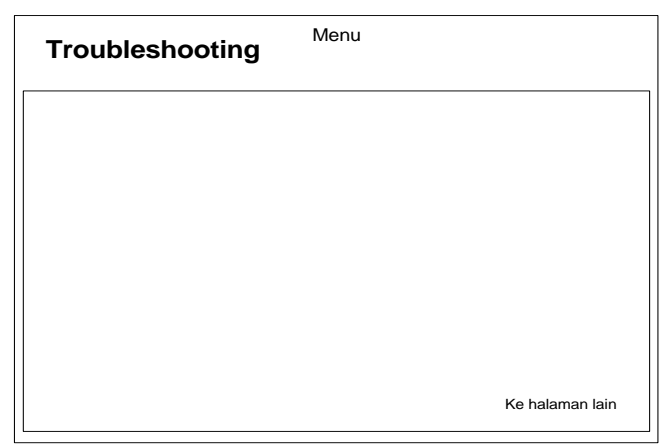

Gambar 5 Rancangan Menu Troubleshooting

GUI menu Pengenalan Hardware ditunjukkan pada Gambar 6. Hasil inplementasi dari menu utama dapat dilihat pada Gambar 7.

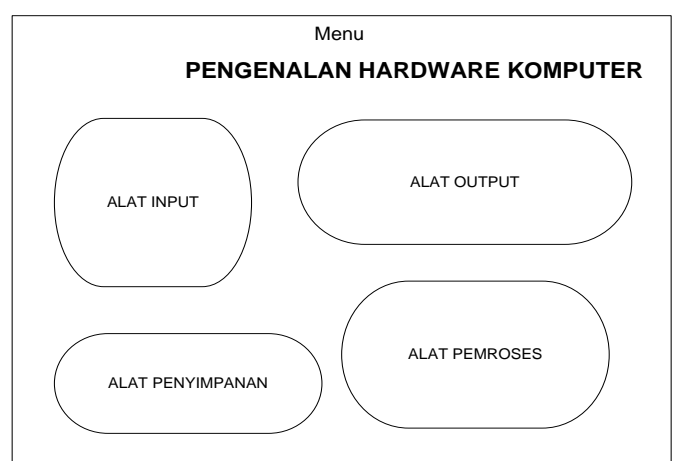

Gambar 6 Menu Pengenalan Hardware

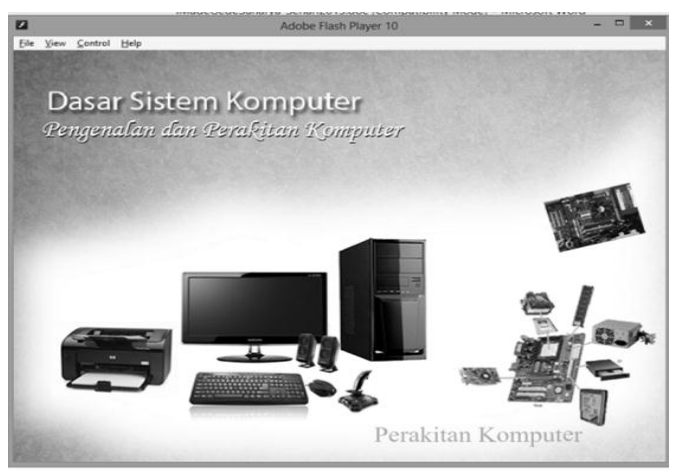

Gambar 7 Implementasi menu Utama 
Menu Pengenalan Hardware digunakan untuk memperlihatkan jenis-jenis hardware yang digunakan dalam perakitan yang ditunjukkan secara berkelompok berdasarkan jenisnya. Hasil Implementasi

\section{Menu Pengenalan Hardware ditunjukkan pada Gambar 8.}

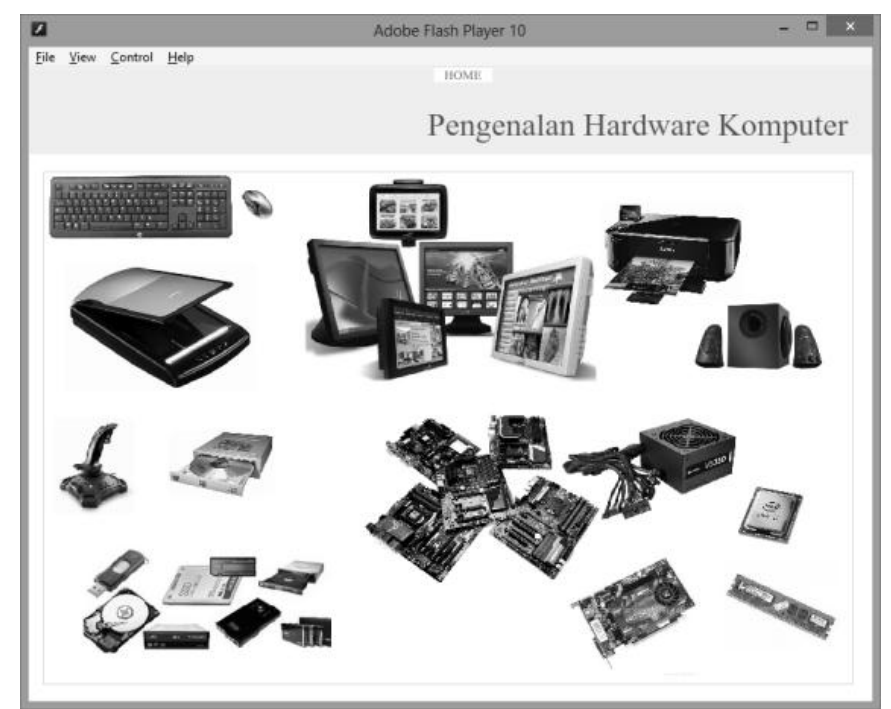

Gambar 8 Impementasi Menu Pengenalan Hardware

Menu Perakitan Komputer casing. Hasil Implementasi memperlihatkan Video untuk melakukan Perakitan komputer ditunjukkan perakitan komputer tanpa menggunakan casing dan perakitan komputer dengan pada Gambar 9.

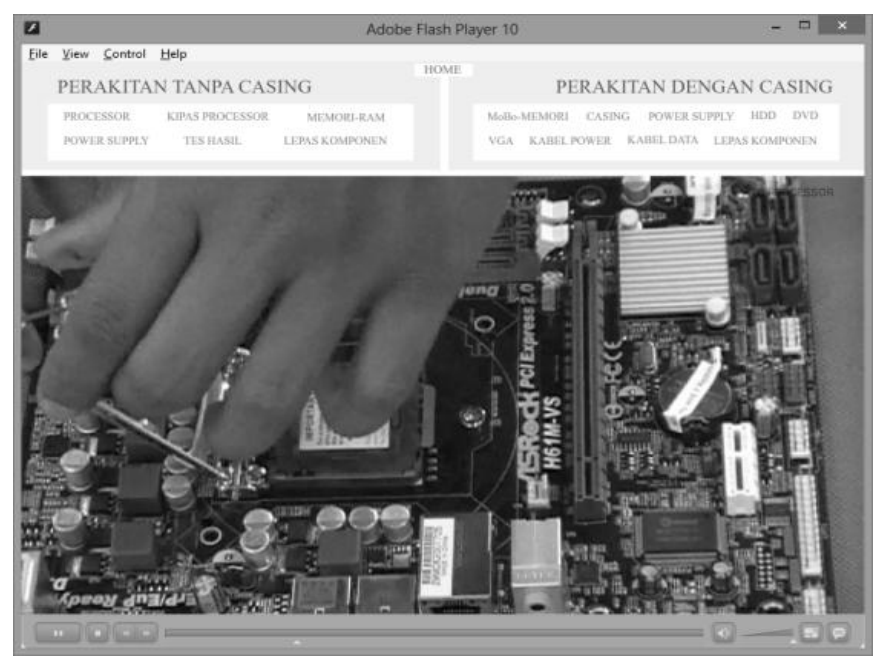

Gambar 9 Implementasi menu Perakitan Komputer 
Menu Troubleshooting digunakan untuk menampilkan beberap tips untuk melakukan pencaringa kerusakan pada sebuah komputer. Hasil implementasi Menu Troubleshooting dapat dilihat pada Gambar 10.

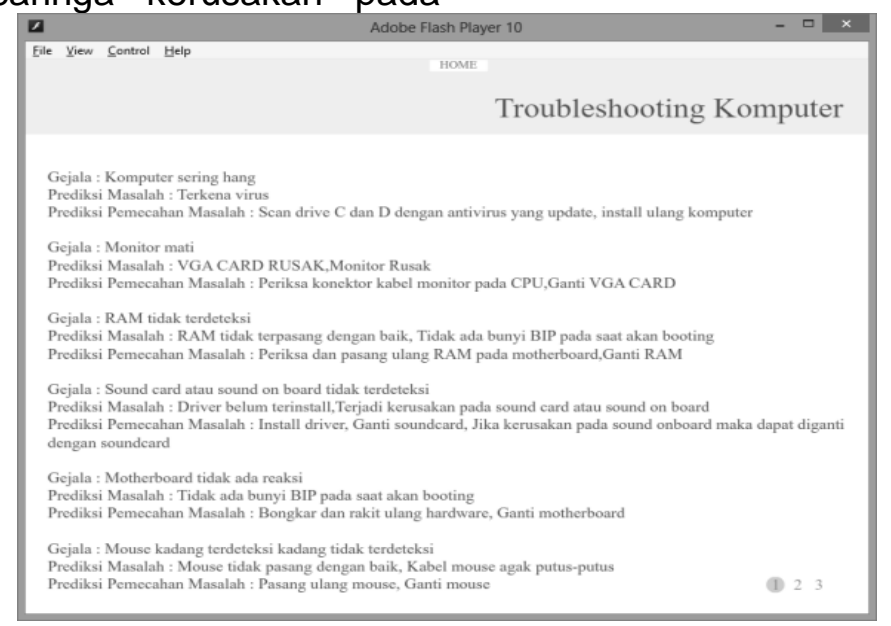

Gambar 10 Hasil Implementasi Menu Troubleshooting

Pengujian terhadap hasil implementasi dilakukan melalui tahapan pengujian fungsionalitas, pengujian ahli isi dan ahli media, pengujian perorangan, pengujian terbatas.

Rerata respon mahasiswa terhadap pengembangan media anime adalah 43,57 yang menunjukkan secara umum bahwa pengembangan media anime dalam kategori sangat positif. Secara rinci $84,4 \%$ dalam kategori sangat positif dan 15,6\% dalam kategori positif.

Media Anime ini dapat digunakan untuk pembelajaran Dasar Sistem Komputer bahasan Instalasi Hardware karena susunan dari Media Anime ini sudah sesuai dengan pembelajaran tersebut. Pembelajaran diawali dengan pengenalan hardware komputer dengan menggunakan menu pengenalan hardware pada Media, dilanjutkan dengan perakitan tanpa menggunakan casing dengan menggunakan menu Perakitan Tanpa Casing yang menyediakan video tutorial langkah demi langkah perakitan komputer tanpa menggunakan casing. Pembelajaran berikutnya adalah perakitan menggunakan casing menggunakan menu perakitan komputer dengan casing. Pada bagian akhir dilakukan pembelajaran troubleshooting komputer yang dapat dilakukan sebagai tahapan untuk mendeteksi kerusakan pada hardware komputer. Keterbaharuan dari Media ini adalah adanya langkah demi langkah yang dalam melakukan perakitan komputer dengan maupun tanpa casing yang dapat digunakan dalam pembelajaran Dasar Sistem Komputer bahasan Instalasi hardware. 


\section{SIMPULAN DAN SARAN}

Berdasarkan hasil dan pembahasan penelitian di atas, maka dapat disimpulkan bahwa pertama, rancangan dan implementasi media anime terdiri dari 3 menu utama, yaitu menu pengenalan hardware, menu perakitan komputer, menu troubleshooting komputer. menu pengenalan hardware terdiri dari 4 sub menu, yaitu alat input, alat output, alat pemroses, alat penyimpanan. Menu perakitan komputer terdiri dari submenu perakitan tanpa casing dan perakitan dengan casing. Kedua, respon mahasiswa terhadap pengembangan media anime matakuliah Dasar Sistem Komputer bahasan instalasi hardware dalam kategori sangat positif. Untuk pengembangan lebih lanjut dapat dilakukan pengembangkan media pembelajaran pada mata kuliah lain yang memiliki karakteristik materi yang abstrak dan kemungkinan untuk dibuat sebuah animasi. Perlu dikembangknnya media ini dengan penambahan pilihan menu suara narasi pada masing-masing menu, sehingga memudahkan bagi mahasiswa yang lebih mudah belajar dengan cara mendengarkan. Perlu dikembangkan media berbahasa internasional seperti bahasa inggis, sebagai persiapan mahasiswa dalam mengajar pada sekolah-sekolah yang berstandar internasional.

\section{UCAPAN TERIMA KASIH}

Terima kasih kami ucapkan khususnya kepada Lembaga Penelitian Undiksha karena telah memberikan kesempatan untuk melakukan penelitian ini. Terima kasih juga kami ucapkan kepada pihak lembaga Undiksha yang telah memberikan kesempatan dan dana DIPA dengan kontrak penelitian Nomor : 90/UN48.14/PL/2013 dalam penyelesaian penelitian ini.

\section{DAFTAR PUSTAKA}

Darmawan, R., 2006, Pengembangan Model Media Pembelajaran Berbasis Komputer Untuk Pendidikan Desain, SNATI-2006ISSN: 1907-5022, Yogyakarta

Hasrul, 2011, Desain Media Pembelajaran Animasi Berbasis Adobe Flash Cs3 Pada Mata Kuliah Instalasi Listrik 2, Jurnal MEDTEK, Volume 3, Nomor 2, Oktober 2011

Hobban, G.F., Ferry, B., tt, Teaching Science Concepts in Higher Education Classes with Slow Motion Animation (Slowmation), Faculty of Education University of Wollongong, Australia

Kristanto, A., 2011, Pengembangan Model Media Video Pembelajaran Mata Kuliah Pengembangan Media Video/Tv Program Studi Teknologi Pendidikan Fakultas Ilmu Pendidikan Universitas Negeri Surabaya, Jurnal Teknologi Pendidikan, Vol.11 No.1, April 2011 (12-22), Universitas Negeri Surabaya

Lisana, 2011, Pembuatan Aplikasi Multimedia Pembelajaran Tentang Cara Berkendara yang Baik, Jurnal Teknologi Informasi, Vol .1, No.2, November 2011

Rahman,A.A., Ishafit, 2011, Perancangan Media Pembelajaran Fisika Berbasis Animasi Komputer Untuk Sekolah Menengah Atas Pokok Bahasan Hukum Newton 
Tentang Gerak, Prosiding Seminar Nasional Penelitian, Pendidikan dan Penerapan MIPA, Fakultas MIPA, Universitas Negeri Yogyakarta, 14 Mei 2011

Rahmattullah, M., 2011, Pengeruh Pemanfaatan Media Pembelajaran Film Animasi Terhadap Hasil Belajar, Edisi Khusus No. 1, Agustus 2011, ISSN 1412-565X

Robbins, S., Kay A.R., 1998 A microprogramming animation, IEEE Transactions on Education 41.4 : 293+. Academic OneFile. Web.

Rosen, Y., 2009 The Effects of an Animation-Based On-Line Learning Environment on Transfer of Knowledge and on Motivation for Science and Technology Learning. Journal of Educational
Computing Research . Academic OneFile.

Santyasa ,I.W., 2009, Metode Penelitian Tindakan Kelas, Pengembangan, Korelasional, Kausal Komparatif, dan Eksperimen, Lembaga Penelitian Universitas Pendidikan Ganesha, Singaraja

Sudrajat, A., 2009, Media Pembelajaran, http://akhmadsudrajat.

wordpress.com, (Diakses tanggal : 15 Maret 2010).

Sunarya, I.M.G., Wirawan,I.M.A., 2010, Pengembangan ANIME (Animation Learning Media) untuk Pembelajaran Komunikasi Data Bahasan Protokol dan Arsitektur Protokol, Laporan Penelitian Institusional Pemula, Universitas Pendidikan Ganesha, 2010. 